\title{
Justification of development of flax production on reclaimed lands of Polissia
}

\author{
Tarariko Yu. ${ }^{1}$, Melnychuk A. ${ }^{2}$ \\ ${ }^{1}$ doctorofAgrarian Science,Corresponding Member of NAAS \\ ${ }^{2}$ Candidate of Agricultural Sciences \\ ${ }^{1}$ Institute of Water Problems and Melioration of NAAS, \\ St.Vasylkivska, 37, c.Kyiv, 03022, Ukraine \\ ${ }^{2}$ Institute of Agriculture of Polissya of NAAS, \\ Kyiv highway, 131, c. Zhytomy, 10007, Ukraine \\ e-mail: ${ }^{1}$ urtar@bigmir.net, ${ }^{2}$ isgpo_zt@ukr.net \\ Received on 18.10.2017
}

The purpose. To determine value of flux in formation of economic indexes of agrarian production at contemporary technological opportunities depending on different factors, in particular, on conditions of growing and level processing products. Methods. Field, computer simulation modeling, economicstatistical. Results. At allocation of $20 \%$ of sown area for flux in comparison with only grain specialization (at security of regulation of water-air and nutritive regimes of soil) the net profit (depending on the level of processing linen raw material) will make 650-2200 standard units/hectare accordingly. For reaching such results capital expenditures on reconstruction of reclamative system, purchase of hardware components for growing and processing linen raw material will make approximately 4800 standard units / hectare with pay-back period up to 3 years. Conclusions. Engaging to grain crop rotation of flux with realization of stock will enable to increase net profit in 1,4 times - up to 650 standard units/hectare. Due to own processing of stock for fiber the profitableness will increase up to 1500 , for thread - up to 2200 standard units/hectare. To create such infrastructure it is possible gradually, without engaging credit resources, owing to purposeful use of profit for formation of its separate components.

Key words: flux, stationary experience, conditions of humidification, processing, economic efficiency.

Until 1990, flax was grown in 86 districts of 9 regions of Ukraine. The primary cultivation of raw materials was carried out by 46 flax mills with a production capacity of 93.3 thousand tons of fiber per year. Another 65flax factories were part of the 1500 collective farms and state farms growing flax, and had a total production capacity of 32 thousand tons per year. As of 2011, flax fiber was produced by Chernihiv and Sumy regions - respectively 500 and 300 tons. There were 2 flax factories in Rivne and Zhytomyr [1, 2].

In the process of processing various information sources, it became clear that the value of flax in the formation of economic indicators of agrarian production could now be quite significant [3-5]. At the same time, the impact of this culture on the level of economic efficiency can vary significantly depending on various factors, in particular weather conditions, keeping up to cultivation technologies, and the depth of processing of products [5-8]. In order to clarify the aspects of economic expediency of the industry of flax [9] in the reclaimed lands of the Right Bank Polissya on condition of on the plant specialization of production basing on the information gained by stationary research with typical sized agricultural enterprise, taken as an example model research was carried out.

The purpose of the research - to establish the value of flax in the formation of economic indicators of agrarian production according to modern technological possibilities, depending on various factors, in particular the conditions of cultivation and the depth of processing of products. 
Research methods. To establish the expediency of attracting flax to the structure of sowing areas were seed, the crop data obtained in the stationary agrotechnical research of the Institute of Agriculture of the Polissya NAAS [10], located on the soddy-medium podzolic sandy soil, that has the following agrochemical characteristics: the content of humus is $0.86-0.94 \%$, total nitrogen $-0.050 \%$, mobile compounds of phosphorus - 23-24 mg / kg of soil and Potassium -14-23 mg / kg of soil, $\mathrm{pH}_{\text {salt }}-4.5, \mathrm{Hr}-$ $2.4 \mathrm{mg}$-equivalent/ $100 \mathrm{~g}$ of soil. Sown area of the plot is $102 \mathrm{~m}^{2}$, accounting $-60 \mathrm{~m}^{2}$, repetition of 4 times, accommodation - randomize. For simulation, the average and maximal observations in the history of observations were used on the control without fertilizers and on the background of NPK. The average yield on the control reflects the natural fertility background, the maximum on the control - simulates the work of the reclamation system, the average against the NPK background - the optimization of the nutrient regime of the soil, maximum at the background of the NPK - simultaneous improvement of the water-air and nutrient regimes of the soil (tabl 1, picture).

The modeling of various scenarios for the development of agrarian production was carried out on the example of land use of LLC Ukrainian Food Alliance, located in Korostensky district of the Zhytomyr region. In the lease of the farm there are 2850.5 hectares of arable land, located within the village councils of the villages of Kholosne, Domoloch and Obidothy.

The variants of purely grain specialization with 4-way crop rotation and the average field size of 712.6 hectares were considered and with the involvement of the flax with the formation of a 5-way crop rotation with an average field size of 570.1 hectares. It was considered that, in addition to flax, crop rotation included the main grain crops of the region, giving the commodity products for sale: wheat and rye of winter, oats and corn. In total 16 variants of the branch structure of the enterprise were compared with different conditions of nutrition, humidity and depth of processing of products. This, in the first place, made it possible to establish the sequence and stage of interdisciplinary optimization based on the development of flax growing.

Basing on the average for 2014-2016, statistical data on the cost price and the price of grain sales in Zhytomyr region production costs, gross income, net profit and payback periods of capital expenditures for the restoration of a reclamation system and the purchase of equipment for the processing of flax raw materials, are calculated. Production costs are determined taking into account the cost of mineral fertilizers - \$ 75 per hectare and maintenance of the drainage and humidifying system - \$25 perhectare.

Research results. According to the current widespread practice of growing cereals without fertilizers for the average in the area of the cost of grain $\$ 158$ per ton, the total production costs on the arable land of 2850.5 hectares are equal to $\$ 650$ thousand. Gross income from grain sales for the average crop price of $\$ 175$ per tons is makes $\$ 877$ thousand with a net profit of $\$ 226$ thousand, or $\$ 79$ per hectare (table 2).

With the reference to the land use area of LLC "Ukrainian Food Alliance" in case of attracting flaxseed crops to sowing areas in a 5-crop rotation, its area will amount to 570.1 hectares. According to the yield per fiber 5centners per hectare ha and the seeds respectively - 1.7 centners per hectareand sales of products in the form of a trust, this will increase the net profit of the enterprise almost twice - from $\$ 79$ to $\$ 147$ thousand. However, the condition for such an increase is the purchase of a flaxseed agricultural machinery complex with the cost of nearly $\$ 280$ thousand with a payback period of 2 years (see figure).

If there is no market for trusts in the region, the company may purchase equipment for its processing into fiber. Analyzing this variant of development, it should be borne in mind that the complex for the processing of raw materials into fiber has a cost of $\$ 2.5$ million, and production costs will increase from $\$$ 756 to $\$ 1112$ thousand by 1.5 times. At the same time, the implementation of recycled fiber increases the gross income twice half with the formation of net income on the level of $\$ 400$ thousand.

With the application of modern technologies, deeper processing is possible - fibers into threads and twine. To purchase such equipment, it is necessary to spend another $\$ 0,9$ million with the growth of production costs from $\$ 1112$ to $\$ 1468$ thousand, by $25 \%$. In this case, net income compared with the processing of raw materials only into the fiber is more than doubled and reaches the level of $\$ 2.3$ million, or $\$ 800$ per hectare, and the payback period of capital costs is quite acceptable and is about 2 years. 
Due to the systematic use of fertilizers, the productivity of crops increases, therefore while cultivativy only grain crops with additional cost $\$ 75$ per hectare net profit by almost $\$ 90$ per hectare - from $\$ 79$ to $\$ 166$ per hectare. In case of introduction of flax in crop rotation, this indicator due to mineral fertilizers increases with the sale of the scutched flax on $\$ 110$ per hectare- from $\$ 147$ to $\$ 257$ per hectare, fiber on $\$ 179$ per hectare - from $\$ 398$ to $\$ 577$ per hectare, twine and threads - on $\$ 297$ per hectare- from \$ 816 to $\$ 1113$ per hectare.

At the same time, the payback period of agricultural machinery for growing and harvesting scutched flax is markedly reduced. Creation of a system of active regulation of the air-water regime of the soil on the whole territory of the land use of this enterprise requires significant investments, which, according to our experts estimates, reach $\$ 3525$ per hectare or more than $\$ 10$ million on the whole area.

However, the optimization of the conditions of moisture far exceeds the effect of mineral fertilizers and makes it possible to bring net profit for growing crops to $\$ 315$ per hectare, for the sale of scutched flax up to $\$ 381$, fibers - up to $\$ 711$ and threads up to $\$ 1264$ per hectare. At the same time, if we consider acceptable payback period of the project 3-4 years, then from this point of view, only the last variant with the return of capital costs after 4 years can be promising.

Systematic application of mineral fertilizers in favorable conditions of humidification for purely grain specialization will increase net income to $\$ 454$ per hectare, the use of flax crop rotation will allow to increase this figure to $\$ 648$ per hectare, which does not provide a sufficiently rapid return of costs on infrastructure, in particular on the drainage-humidifying system. For a deeper processing of scutched flax into fiber, profitability increases to $\$ 1533$ per hectare, into twine and threads - up to $\$ 2226$ per hectare with acceptable payback periods of capital costs.

Consequently, with the lack of own funds to invest in the rapid development of this agricultural enterprise or the inability to attract the necessary credit resources, an evolutionary direction of improving of its branch structure can be proposed. By average multi-year indicators of grain crop yields at the systematic application of mineral fertilizers, annual net profit is at \$470 thousand (Model № 5). This amount is quite enough for the purchase of technical means for the cultivation, harvesting and primary processing of trusts and flax seeds. The following year, as a result of the sale of grain and flax produce, net profit will amount to $\$ 732$ thousand (Model № 6). Equipment for the processing of scutched flax into fiber has a cost of $\$ 2.5$ million and for the pre-specified profitability the company will be able to purchase it in 3.4 years. Deeper processing will allow you to increase net profits to $\$ 1644$ thousand (Model № 7 ) and next year to buy equipment for the production of yarn and twine with profitability of $\$ 3171$ thousand (Model № 8). According to the approximate cost of reconstruction and construction of a reclamation system with active regulation of the air-water regime of the soil, $\$ 10$ million (Model № 9), the term of these works will be 3.2 years, with a net profit of $\$ 6.3$ million (Model №16). That is implementation of the project due to the gradual development of the infrastructure will takes about 10 years (see picture). With availability a sufficient amount of own or credit financial resources, capital costs will be paid back in 2 - 3 years.

1. Crop yields for optimizing water-air and nutrient soil regimes, hundredweight per hectare

\begin{tabular}{|c|l|c|c|c|c|c|}
\hline $\begin{array}{c}\text { Fertilizer } \\
\text { system }\end{array}$ & Productivity & Wheat & Rye & Oats & Flax & Corn \\
\hline \multirow{2}{*}{ K } & Average & 14,1 & 16,9 & 11,8 & 4,8 & 15,1 \\
& Maximum & 27,6 & 26,5 & 19,7 & 5,5 & 25,3 \\
\multirow{2}{*}{ NPK } & Average & 15,7 & 19,4 & 17,6 & 6,4 & 24,6 \\
& Maximum & 28,6 & 30,0 & 39,2 & 11,8 & 58,5 \\
\hline
\end{tabular}

Years of research 


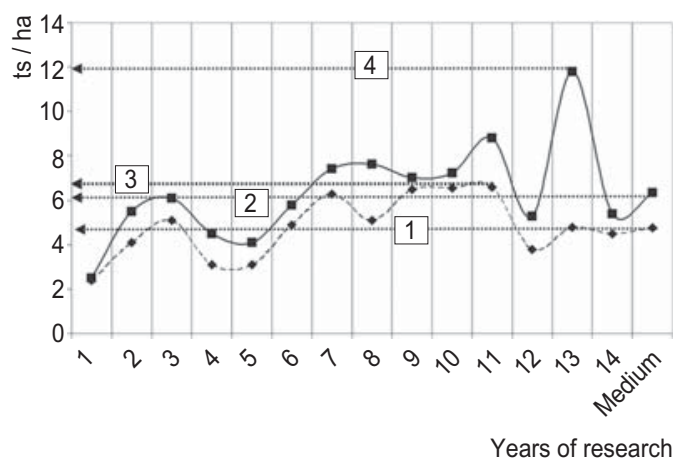

Factors for improving the condition of the flax cultivation: 1 - natural background; 2 - water - air regime; 3 nutrition regime; 4 - nutrition and water-air regimes: - - - control; - - - nPk

2. Indicators of economic efficiency of growing and processing flax in different conditions of nutrition and moistureg

\begin{tabular}{|c|c|c|c|c|c|c|c|}
\hline Model & Conditional name* $^{*}$ & $\begin{array}{l}\text { Costs, } \\
\$ \text { thousands }\end{array}$ & & $\begin{array}{l}\text { Gross income, } \\
\text { \$thousand }\end{array}$ & Net profit & & $\begin{array}{l}\text { Payback } \\
\text { periods, years }\end{array}$ \\
\hline & & capital & production & & \$ thousand & $\$$ thousand/ha & \\
\hline 1 & «No fertilizers-grain» & - & 651 & 877 & 226 & 79 & - \\
\hline 2 & «No fertilizers-scutched flax» & 279 & 756 & 1177 & 421 & 147 & 1,9 \\
\hline 3 & «No fertilizers - fiber» & 2779 & 1112 & 2245 & 1134 & 398 & 2,5 \\
\hline 4 & «No fertilizers - thread» & 3679 & 1468 & 3794 & 2326 & 816 & 1,65 \\
\hline 5 & «NPK - grain» & - & 693 & -1406 & 473 & 166 & - \\
\hline 6 & «NPK - scotched flax» & 279 & 808 & 19544 & 732 & 257 & 1,1 \\
\hline 7 & «NPK - fiber» & 2779 & 1264 & 20 & 1644 & 577 & 1,7 \\
\hline 8 & «NPK - thread» & $3679<$ & 1720 & 4 & 3171 & 1113 & 1,2 \\
\hline 9 & «DHS - grain» & $10048<$ & 668 & 1564 & 897 & 315 & 11,2 \\
\hline 10 & «DHS - scutched flax» & 10327 & 791 & 1878 & 1087 & 381 & 9,5 \\
\hline 11 & «DHS - fiber» & 12827 & 1261 & 3289 & 2028 & 711 & 6,3 \\
\hline 12 & «DHS - thread» & 13727 & 1732 & 5334 & 3602 & 1264 & 3,8 \\
\hline 13 & «NPK+DHS - grain» & 10048 & 1139 & 2460 & 1321 & 454 & 7,6 \\
\hline 14 & «NPK+DHS - scotched flax» 10327 & 1241 & 3089 & 1848 & 648 & 5,6 & \\
\hline 15 & «NPK+DGS - fiber» & 12827 & 1241 & 5611 & 4370 & 1533 & 2,9 \\
\hline 16 & «NPK+DHS - thread» & 13727 & 2923 & $9267 \longrightarrow$ & 6344 & 2226 & 2,2 \\
\hline
\end{tabular}

«No fertilizers» - average perennial crop yields on the natural background of fertility; «NPK» — average perennial crop yields for systematic use of mineral fertilizers; "DHS» - imitation of work of the drainage-humidifying system with the yield of crops in the most favorable years; "NPK+DHS» - imitation of work of the drainage-humidifying system with the yield of crops in the most favorable years at systematic use of mineral fertilizers; "grain» - growing only grains in 4 fields of crop rotation with an average field of 712,6 hectares; "scutched flax» - growing with grains in 5 fields of crop rotation flax with an average field of 570,1 hectares and sale of grain and scutched flax without processing; «fiber» - involvement in infrastructure of equipment for processing scutched flax into fiber; «thread» — involvement in infrastructure of equipment for processing fiber into thread and twine.

\section{Conclusions}

The information base of long-term agronomic experiments is theoretical basis not only for substantiation of economically efficient systems of agriculture and agrotechnologies, but also for the formation of the crop area structure adapted to the agro-resource potential of certain agricultural territories. Regarding the soil-climatic conditions of the Right-bank Polissya on condition of optimizing of the water-air and nutrient regimes of the soil and the purely planting specialization of agrarian production without livestock raising, cultivation of scutched flax in the grain crop rotation will enable to increase the net profit by 1.4 times - up to $\$ 650$ per hectare. This may be in order of magnitude higher than the current widespread practice without adjusting of the conditions of moisture and fertilizer. The organization of the own processing of the scutched flax into the fiber will be accompanied by an increase in profitability to the level of $\$ 1500$ per hectare, on the thread - to $\$ 2200$ per hectare with a payback period of capital costs of 3-4 years.

\section{Bibliography}

1.Krugla H.A. Vergunov V.A. (2002).History of flax development in Ukraine: teach. Manual. Kherson: Adams, $168 \mathrm{p}$.

2. Harvest of crops, fruits, berries and grapes in Ukraine: stat. save.State Statistics Committee of Ukraine.(2011). Kyiv, 174 p.

3. Korolyov K.P.(2015). Economic efficiency of cultivating the innovative varieties of flax-dolgunts "Mayak".Synergy.No. 2. P. 77 - 80. 
4. Yesipchuk T.P.(2003). Strategic directions of development of foreign trade in products of flaxsubcomplex of Ukraine.Economy of AIC.No. 11.P. 141 - 147.

5. Tkachuk V.I.,Kravchuk N.I.(2008).Formation of competitiveness of flax produce: monogr. Kyiv: Phoenix. 193 p.

6. Handbook of Agronomist for Agricultural Meteorology. Non-Black Earth Zone of the European part of the RSFSR; ed. I.G.Gringofa.(1986). Leningrad:Hydrometeoizdat. P. 383 - 392.

7. Len-dolgunets (recommendations on cultivation). (2007).KPUP "OrshanskayaTypografiya". 20 p.

8. Methodical recommendations for introduction of scientifically grounded system of agriculture in farms of Zhytomyr region. (1982). Zhytomyr. P. 135 - 141.

9. PriyamachukT.Yu. Shtanko T.A., Kovalev V.B. (2017).Development of the Flax Industry in Ukraine.Visn.agrarscience. No. 7.P. 68 - 75.

10. Long-term stationary field experiments of Ukraine. Register of Certificates.UAAS, National Academy of Sciences of Ukraine "Institute of Soil Science and Agrochemistry them. O.N. Sokolovsky"; rare P.I. Kovalenko and others.Kharkiv: "Printing house number 13". 120 p. 